\title{
SUMMARIES
}

\section{Dairy Cattle}

Fatty acid composition of milk produced under systems of different intensity and milking practices in the North East of England

S Stergiadis, C Leifert, C J Seal, M D Eyre, G Butler

2 Concentration of $\beta$-casein variants in UK retail milk

PC Aikman, R H Brown, T M Gibson, K E Kliem, D I Givens

3 Persistency of the effect of dietary milled rapeseeds on the milk fatty acid composition of lactating cows fed maize silage-based diets

K E Kliem, K J Shingfield, A K Jones, D I Givens

Effect of rumen boluses containing iodine, selenium and cobalt administered to dry Holstein dairy cows on the circulating concentration of immunoglobulin $\mathrm{G}$ in the calves

M T Rose, T D Cratchley, S Pearson

5 Effect of concentrate build-up strategy in early lactation on production performance, health and fertility of high-yielding dairy cows

R A Law, S McGettrick, C Ferris

6 Effect of exogenous long chain fatty acids on cytosolic triacylglycerol content of bovine mammary epithelial cells

E Vargas-Bello-Pérez, A M Salter, J J Loor, P C Garnsworthy

$7 \quad$ Calving ease and the subsequent fertility and calving performance of the dairy cow: retrospective analysis from a UK farm

A C Barrier, M J Haskell

$8 \quad$ Predisposing factors for culling in first lactation Holstein-Friesian heifers

D Chiumia, M G G Chagunda, D J Roberts, A I MacRae

9 The response of grazing dairy cows to a 'flat rate' or a 'feed-to-yield' concentrate allocation strategy

A J Dale, C P Ferris, S McGettrick

\section{Developments in National Genetic Evaluations}

10 The benefits of Computed Tomography (CT) scanning in UK sheep flocks for improving carcase composition K Moore, K Mclean, L Bunger

11 Use of farmer recorded mastitis data to improve the genetic evaluation of udder health in UK dairy cattle T Pritchard, M Coffey, R Mrode, K Moore, E Wall

12 Use of national cattle movements data to enhance the genetic evaluation of lifespan in UK dairy cattle C Duthie, T Pritchard, R Mrode, M Coffey, E Wall

Genetic relationship of lameness with milk yield, body condition score and reproductive traits in primiparous Holstein cows

A Kougioumtzis, G Oikonomou, G Arsenos, G Banos

14 Genetic correlations between calving ease and fertility traits in UK Holstein Friesian heifers S A E Eaglen, J A Woolliams, M P Coffey, E Wall

15 A model for deriving economic weights for calving ease in UK dairy cattle

E Wall, M Coffey, A Sadeghi-Sefidmazgi, P Amer 
Genetic and non-genetic factors influencing Fasciola hepatica antibodies in milk in UK Holstein Friesian cattle

C Hayhurst, AB Forbes, DJL Williams, MD Royal

\section{Equine Performance, Nutrition and Health}

18 Review of current knowledge of equine demography and movements within Great Britain

J Yates, T D H Parkin, M Casey, D J Mellor, R R Kao, L A Boden

19 Determination of the sorption and desorption isotherms of donkey hoof horn L Hopegood, S N Collins, J D Reilly

The validation of infrared thermography as a non-invasive tool to assess welfare in the horse (Equus caballus) K Burton, C Hall, C Wells, E Billett

Comparison of the zonal moisture content of the Stratum medium of donkey hoof horn to the zonal moisture content of the Stratum medium of horse hoof horn

L Hopegood, S N Collins, J D Reilly

Identification of the influence of moisture content on the mechanical properties across the Stratum medium of donkey hoof horn

L Hopegood, S N Collins, J D Reilly

A comparison between industry standard method of semen analysis and the use of SpermVision ${ }^{\mathrm{TM}}$ for the evaluation of the measureable parameters of chilled stallion spermatozoa T Coop, A Mills

A comparative antibody study of the potential susceptibility of Thoroughbred and Non-Thoroughbred horse populations in Ireland to equine influenza virus

S Gildea, S Arkins, A Cullinane

\section{Welcome Research Papers (avtrw)}

26 Modulation of endothelial cell signalling and function by parstatin, a putative anti-angiogenic peptide C E Farrar, E Garonna, N Kirkby, T Warner, C P D Wheeler-Jones

Muscle fibre profile number and size distribution changes with age in mdx mice

R L Terry, D J Wells

Proteomic analysis of the early osteoarthritic equine cartilage secretome M Peffers, R Beynon, P Clegg

\section{Diagnostics (AVTRW)}

30 Validation of a real-time PCR to detect Coxiella burnetii in placenta and abortion samples from ruminants, and application of the PCR as a tool to monitor an infected UK goat herd

R M Jones, D F Twomey, S Hannon, J Errington, G C Pritchard, J Sawyer

31 Acute phase protein measurements in metabolic profiles in UK dairy herds A Macrae, E Burrough, J Forrest, T Parkin, E McCulloch, P D Eckersall

A metabolomic investigation of milk in bovine mastitis R Mansor, K Burgess, D Barrett, P Whitfield, D Eckersall

Newly emerging veterinary diagnostic technologies: exploring attitudes, behaviours and wider social impacts A Bruce 
M L Bermingham, I G Handel, E J Glass, J A Woolliams, B M de Clare Bronsvoort, R A Skuce, A R Allen, S W J McDowell, S H McBride, S C Bishop

\section{EPIDEMiology (AVTRW)}

35 The prevalence of helminth infestations in hedgehogs admitted to wildlife centres across England S Orton, B Heayns, E Martin

A cross sectional study on the point prevalence and risk factors for Habronema in working equids in central Ethiopia

G Chaters, M Getachew, S Reid

37 Assessment of risk factors for antimicrobial resistance diversity in dairy cattle A E Mather, W M Sischo, D T Haydon, D J Mellor, S W J Reid

\section{Veterinary Education (AVTRW)}

38 The influence of interview on the selection of students into a veterinary medicine degree programme N P H Hudson, S M Rhind, D J Shaw, G M Giannopoulos, C E Bell, G T Pearson, C A Phillips, R J Mellanby

Predictors of success on the veterinary undergraduate course: evaluating variables within the student intake and correlating with performance

N P H Hudson, R J Mellanby, D J Shaw, G M Giannopoulos, C E Bell, G T Pearson, C A Phillips, L Dalziel, S M Rhind

$40 \quad$ What are our final year veterinary students seeing? Finding the evidence

M L Brennan, R S Dean

41 The use of a blackboard wiki as a tool for teaching evidence-based veterinary medicine M Steele, N P Crabb, L J Moore

Development of the Animal Welfare Associated Reflective Exercise (AWARE): a self-directed learning tool to promote ethical reflection in pre-clinical veterinary students

C Batchelor, D C J Main, V Dale, D E F McKeegan

Measuring ethical reasoning ability in first year veterinary students using the Defining Issues Test

C Batchelor, D E F McKeegan

\section{Pig Health and Disease (avtrw)}

44 Ten years of Post-weaning Multi-systemic Wasting Syndrome in England: retrospective study on morbidity, breeds used and farmers' perception P Alarcon, M Velasova, K D C Stärk, D U Pfeiffer, D Werling, B Wieland

45 Pigs and the H1N1 pandemic: innate immune responses in experimentally infected pigs G A White, S P Dunham, S M Brookes, A Germundsson, F Garcon, A Núñez, K-C Chang, I H Brown, COSI Consortium

46 Epidemiological investigation of the efficacy of PCV2 vaccination on PMWS severity in English pig farms M Velasova, P Alarcon, D Werling, Y Chang, A Nevel, B Wieland

47 Dynamics of herd infection: multiple enteric pathogens in young pigs H E Davies, L Hancox, C E R Dodd, S Tötemeyer, J Wiseman, K H Mellits

48 British Pig Health Scheme: use of slaughterhouse data to inform infectious disease control in pig farms H Holt, P Alarcon Lopez, M Velasova, D Pfeiffer, B Wieland 


\section{Application of Molecular Genetic Tools to Animal Science}

Finding the mutation causing early calf mortality in a pedigree breed of cattle as the basis for a genetic test to identify carriers of an autosomal recessive condition

G E Pollott, D C Wathes, J S Brickell, A M Clempson, S Hill

Polymorphisms in mitochondrial transcription factor A (TFAM) are associated with growth and fertility in dairy cows

A Clempson, G E Pollott, J S Brickell, N E Bourne, N Munce, D C Wathes

Results of genotyping UK dairy bulls with a high density DNA array

G Banos, E Wall, R Mrode, M P Coffey

A meta-analysis of public microarray datasets reveals the transcriptional immune response to multiple pathogens in the chicken

G Weaver, M Watson, P Kaiser

Use of non-invasive methods to collect DNA for genome wide analysis from companion animals

A T French, R Ogden, C Eland, G Hemani, B Corcoran, K M Summers

Genome wide analysis of mitral valve disease in Cavalier King Charles Spaniels

A T French, R Ogden, C Eland, G Hemani, R Pong-Wong, B Corcoran, K M Summers

Characterisation of a disease resistance QTL in Atlantic salmon using next-generation sequencing R D Houston, J W Davey, S C Bishop, K Gharbi, J C Mota-Velasco, A E Tinch, J E Bron, J B Taggart

Genome-wide Association using a 60k SNP chip to explore the genomic control of boar taint in pigs

S J Rowe, B Karacaoren, DJ de Koning, I Velander, C S Haley, A L Archibald

\section{Understanding Health Disease Traits}

57 Bayesian modelling to estimate the sensitivity of the Immuno-Magnetic Separation (IMS) method of detecting Escherichia coli $\mathrm{O} 157$ in bovine faecal samples

M Nath, G T Innocent, G J Gunn, I J McKendrick

The impacts of climate change on Fasciola hepatica risk in the UK

N J Fox, P C L White, C J McClean, G Marion, A Evans, M R Hutchings

Implications of host genetic variation on the risk and prevalence of infectious diseases transmitted through the environment

A B Doeschl-Wilson, J Conington, R Davidson, T Roughsedge, M R Hutchings, B Villanueva

Investigating within-farm and between-farm disease transmission interactions: implications for the control of British poultry diseases

S Nickbakhsh, L Matthews, S W J Reid, R R Kao

\section{SHEEP I}

Effect of the Texel muscling quantitative trait locus (TM-QTL) on fore quarter, hind quarter and saddle weights, weight distribution and carcass composition in purebred Texel lambs J M Macfarlane, N R Lambe, K A McLean, B T Wolf, W Haresign, L Bünger

An evaluation of the effects of maturity of maize at harvest, grass silage feed value and concentrate feed level on finishing lamb performance

T W J Keady, J P Hanrahan 
Trans-generational effects of nutrient restriction during early and mid-pregnancy on reproductive function in Scottish Blackface and Suffolk sheep

C J Ashworth, C M Dwyer, C O Hogg, S L Etherington, N Itani, K Landers, J A Rooke

Effects of the Texel muscling quantitative trait locus (TM-QTL) on carcass and VIA traits in purebred Texel lambs

A Y Masri, J M Macfarlane, N R Lambe, W Haresign, L Bunger

67 Effect of the Texel muscling quantitative trait locus (TM-QTL) and sex on meat quality parameters of the semimembranosus muscle of purebred Texel lambs

C R Craigie, N R Lambe, J M Macfarlane, C A Maltin, S T Morris, R Roehe, L Bunger

A comparison of growth and carcass characteristics of hill lambs finished on a selection of forage-based diets

R W Annett, A F Carson

69 Breed and sex effects on spine characteristics in sheep

C L Donaldson, N R Lambe, J M Macfarlane, K A McLean, C A Maltin, L Bunger

Incorporation of fluorescent markers into lamb finishing rations to aid detection of faecal contamination in the abattoir

S Sagatarame, H R Fleming, V Theobald, M R F Lee

The effects of beta-adrenergic agonist (BA) and growth hormone (GH) on factors involved in determining skeletal muscle fibre type in growing lambs

Z C T R Daniel, P J Buttery, T Parr, J M Brameld

72 The effects of beta-adrenergic agonist (BA) and growth hormone (GH) on lamb growth characteristics and muscle proteolytic systems

Z C T R Daniel, E Pouliot, P J Buttery, J M Brameld, T Parr

\section{Methane}

73 Remote measurement of enteric methane from dairy cows under different activities M G G Chagunda, A Bagnall, D Bell, D J Roberts

Variation in methane emissions measured during milking for individual dairy cows under commercial conditions P C Garnsworthy, J Craigon, J H Hernandez-Medrano, N Saunders

Effect of feeding milled rapeseed on methane emission and milk fatty acid composition in lactating dairy cows L A Crompton, J A N Mills, K E Kliem, C K Reynolds

Effect of herd expansion and reduced inorganic fertiliser use on the global warming potential of four divergent dairy production systems

S A Ross, M G G Chagunda, C F E Topp, R A Ennos

77 Effect of ranking on phenotypic residual feed intake (RFI) and diet type on ruminal menthanogenic populations in beef heifers

C A Carberry, D A Kenny, A K Kelly, C J Creevey, S M Waters

Will extended lactations in dairy systems result in a reduction in greenhouse gas emissions?

G E Pollott, E Wall, M P Coffey

Predicting methane emissions from beef cattle on different grasslands - does the prediction equation matter? P Ricci, A Waterhouse 


\section{Beef Cattle Nutrition}

81 An analysis of BCMS data to determine the breed composition of the UK beef herd D L Todd, J A Woolliams, T R Roughsedge

Effect of concentrate feed level on the performance of maize silage fed dairy-bred bulls S P Marsh

Protein availability of different co-products from bio-ethanol processing to dairy cattle Arash Azarfar, Peiqiang Yu

An evaluation of crimped maize grain for finishing beef cattle

S P Marsh, T H Bletcher, M Vickers

Effect of early weaning concentrate pellet size on the performance of artificially reared dairy-bred bull calves S P Marsh, T Lingham

The relationship between physical and chemical characteristics of maize silage and its whole tract apparent organic matter digestibility and in situ degradability

C Rymer, D J Humphries, J S Blake, D I Givens

Near infrared reflectance spectroscopy (NIRS) as a tool for understanding the differences in molecular structure of dry matter: dried distiller's grains with solubles (DDGS) as a feed model

Arash Azarfar, Peiqiang Yu

Effects of maturity stage at harvest and dietary inclusion rate of whole-crop maize silage on intake, feed utilization and performance of growing dairy bulls

K Zaralis, E Nadeau, S Johansson, C Helander, P Nørgaard, M Murphy

Carcass $\mathrm{pH}$, temperature and colour changes during the first 48 hours post slaughter in Aberdeen $\mathrm{x}$ Limousin and Limousin $\mathrm{x}$ Aberdeen Angus steers and heifers

J J Hyslop, D W Ross, E A Navajas, N Prieto, R Roehe, G Simm

Effect of feeding plant oil rich in stearidonic acid on growth and meat quality of Charolais crossbred steers

E J Kim, R I Richardson, K Gibson, N D Scollan

\section{Behaviour ANd Welfare}

91 Achieving animal welfare and sustainability benefits by implementing existing knowledge: case examples in pigs and dairy cattle

D C J Main, H R Whay

The early detection of acute and chronic health challenges in beef cattle from changes in behaviour O Szyszka, B Tolkamp, S A Edwards, I Kyriazakis

Establishing the extent of adverse behavioural reactions in dairy cattle to a leg mounted activity monitor J R D MacKay, M J Haskell

94 The influence of housing dairy heifers with multiparous cows prior to calving on welfare and productivity during the post calving period

A R Boyle, C P Ferris, N E O'Connell

Ewes treated with lipopolysaccharide as neonates bear offspring that are more resilient to pain caused by castration and / or tail docking Evidence for cross-generational effects of perinatal programming?

C Clark, M Mendl, J Murrell

The effect of two dietary regimes on ruminating and lying behaviour of Belgium Blue cross heifers housed over winter

A Tibbott, R Cooke, H Scott-Browne, N Blackie

The effect of a two step weaning method on the behaviour of six month old Belgian Blue crossbred beef calves

H Stevens, N Blackie, J R Amory 


\section{Pigs I}

98 The Green Pig survey: constraints of using peas and faba beans in growing and finishing pig diets L A Smith, J G M Houdijk, I Kyriazakis

99 Nitrogen excretion during the growing-finishing period and its relationships with daily feed intake, feed conversion ratio and production traits in commercial pigs

M Shirali, A Doeschl-Wilson, P W Knap, C Duthie, E Kanis, J A M van Arendonk, R Roehe

Efficacy of $\beta$-glucanase and xylanase blend in mixed grains and grain co-products-based diets for growing/ finishing pigs

E Kiarie, A Owusu-Asiedu, P H Simmins, C M Nyachoti

101 Trial site influences optimal soyabean inclusion level in piglet starter diets

I J Wellock, P Toplis, A Stewart, H M Miller

102 The effect of increasing soyabean level and phytase addition on the performance of newly weaned pigs

P Toplis, I J Wellock, H M Miller

103 Post-weaning performance of pigs offered varying allowances of starter diets

E Magowan, M E E Ball

104 The effect of group gender and diet on finishing pig performance and carcass characteristics

E Magowan, M E E Ball

\section{Pigs II}

105 Can enthalpy and rate of change provide useful practical indices of the thermal loads experienced by livestock in transit?

M A Mitchell, P J Kettlewell, M Villaroel, P Barreiro, M Farish

106 The influence of pre-service weather conditions on farrowing rate in outdoor sows A LeMoine, R D Boyle, H M Miller

107 Effect of altering maternal feed allowance in early gestation on sow and piglet performance at farrowing P D Cottney, E Magowan, M E E Ball

108 The effects of supplementing various levels of chitosan on performance, selected microbial populations and volatile fatty acid concentration in the weaned piglet

A M Walsh, T Sweeney, J J Callan, B Bahar, J V O'Doherty

109 Acute phase proteins as markers for subclinical disease in young pigs

S Athanasiadou, J G M Houdijk, P D Eckersall, C L Low, I Kyriazakis

110 Genetic associations of feed intake behaviour traits with piglet survival and litter size

R Roehe, E M Baxter, P W Knap, A B Lawrence

\section{Ruminant Health and Disease (avtrw)}

111 Is sheep BSE of greater risk to humans than cattle BSE?

C Plinston, P Hart, A Chong, N Hunter, J Foster, P Piccardo, J C Manson, R M Barron

112 Developments in goat transmissible spongiform encephalopathy (TSE) research

W Goldmann, A Bossers, J Langeveld, O Andreoletti, F Lantier, F Barillet, J-M Torres, C Acin, M Groschup, P-L Acutis, U Agrimi, R Nonno, T Sklaviadis, J Grassi

113 Early pre-clinical infection of peripheral tissues in sheep with experimental bovine spongiform encephalopathy

N Hunter, J Foster, M Bruce 
114 Caprine prion gene polymorphism (I142M) associated with low scrapie susceptibility shows high allele frequency in British goat herds

K Ryan, P Stewart, J Foster, D Parnham, A Bossers, W Goldmann

115 Listeriosis in farmed animals identified through Veterinary Laboratories Agency scanning surveillance over the last 9 years

A Otter

116 Reservoir hosts of Leptospirosis excrete urinary IgG specific for Leptospira

R Bonilla-Santiago, J Nally

117 Pathogen-specific inhibition of the innate immune response during bovine mastitis

N Patterson, T Coffey, D Werling

118 A probabilistic elicitation of expert veterinarians' beliefs regarding vaccination against bovine viral diarrhoea virus in dairy cattle and the effect on herd fertility performance

H M Higgins, S Brister, M Green

119 An emerging haemorrhagic syndrome in young calves in Europe: pathology and pathogenesis

S Scholes

120 Evaluation of the reliability, sensitivity and specificity of animal-based indicators of sheep welfare

C J Phythian, P J Cripps, N Toft, E Michalopoulou, P H Jones, D H Grove-White, M J Clarkson, A C Winter, J S Duncan

121 Consequences of plant protein source on the periparturient resistance to parasites in ewes

P Sakkas, J G M Houdijk, S Athanasiadou, I Kyriazakis

122 An improved understanding of bacterial population dynamics in the development of ovine footrot

L A Witcomb, L E Green, E M W Wellington, J Kaler, A U1 Hassan, L A Calvo Bado, R Grogono Thomas, G

F Medley

\section{Companion Animal Health and Disease (avtrw)}

123 Management of over-weight and obese equids in a charitable trust setting: measures of success and failure B Freer, T Hollands, D S Gardner, A Mostyn

124 Acute zinc intoxication in a dog - clinical and pathological findings

R Blundell, F Adam

125 Paravertebral malignant schwannoma in a Horse

G Nikolaou, M de Bonont, U Heitzel

126 Neonatal canine staphylococcal dermatitis

A Philbey, D Taylor, H Thompson

127 Gastric lymphangioma in a dog

C Richardson

\section{Pathogens - host interactions (AVTRW)}

128 Novel SNPs in sheep and cattle TLR5: potential biomarkers for disease resistance and susceptibility?

S A Smith, O C Jann, D Haig, D Werling, R D Emes, E J Glass

129 Eliciting expert perceptions of the efficacy and practicality of pathogen control measures: E coli O157 and human health

P Cross, D Rigby, G Edwards-Jones

130 Comparison of host pathogen interactions in two and three dimensional tissue culture systems: Clostridium difficile and porcine intestinal epithelial cells

K Hillier, M Lovell, P Barrow, S Totemeyer 

pathogen Leptospira

H Collett, E Wood, C Pfarrer, W Wapenaar, S Totemeyer, P Barrow

132 Characterisation of a porcine small intestinal epithelial cell line (IPEC-J2), as a model to study host response to the probiotic Lactobacillus rhamnosus

M King, K Hillier, P Barrow, S Totemeyer

Apparent effects of post-natal infection with Mycobacterium avium on the susceptibility of sheep to copper toxicity one year later

N Suttle

\section{Meat Quality}

$134 \quad$ Improving fatty acid profile in beef muscle

N D Scollan, R I Richardson, E J Kim

Carcasses of Belgian Blue culled cows and growing fattening bulls: 2 meat quality and fat and fatty acids composition in meat pieces

V Robaye, O Dotreppe, J L Hornick, L Istasse, I Dufrasne

136 Application of near infrared hyperspectral imaging to the prediction of meat quality

B W Moss, M Whitworth, A J Gordon, A Chau, K Matthews, A Fearon

Application of hyperspectral imaging to predict intramuscular fat and fatty acid profiles of beef Longissimus dorsi muscle

A Fearon, M Whitworth, B Moss, A Beattie, A Chau, A Gordon, K Matthews

Contribution of ruminal protozoa to the duodenal flow of polyunsaturated fatty acids following feeding on low and high chloroplast-containing diets

S A Huws, A H Kingston-Smith, E-J Kim, M R F Lee, J K S Tweed, M B Scott, N D Scollan

139 Finishing lambs on chicory increases killing out percentage and carcass conformation score without detrimental effects on sensory meat eating quality

J G M Houdijk, A Baker, E A Navajas, R I Richardson, D W Ross

140 Stearidonic acid biohydrogenation by the mixed rumen microbial population in vitro M R G Maia, C A S Correia, S P Alves, A J M Fonseca, A R J Cabrita

Comparison of wheat- versus corn-based dried distillers' grains with solubles on muscle fatty acid composition of feedlot cattle

N Aldai, M E R Dugan, J K G Kramer, J L Aalhus, A R Mantecón, J J McKinnon, T A McAllister

142 Physical qualities, proximate chemical composition and fatty acid profiles of three freshwater fish species harvested from upstream and downstream locations

A S Chaudhry, F Jabeen

143 Meat quality of bulls, heifers and steers sampled at a commercial abattoir

B Moss, A Fearon, M Whitworth, A Chau, E Tolland, D Devlin, E Tollerton, A Gordon, K Matthews

Meat quality characteristics from lambs and sheep produced in the mountainous and the semi-mountainous area in North Greece

A Zervos, E Kasapidou, L Papaloukas, E Sinapis 


\section{Highlights Red}

145 Effects of dietary potassium diformate on feed intake, weight loss and backfat reduction in sows: pre-farrowing till weaning

C Lückstädt

146 Seasonality and heterogeneity in live fish movements and their implications for Scottish aquaculture M Werkman, L A Munro, D M Green, A G Murray, J F Turnbull

147 A study on possibility of using sugar beet molasses in honey bee nutrition

J Modarresi, M Bashtani, A R Fazaeli, H Farhangfar, P Rowlinson, M Ashrafi Gol

148 The effect of Vernonia amygdalina leaf extract on Alloxan induced diabetic rats P Ekeocha, A Ekeocha, T Fasola, K Afolabi

149 Carcasses of Belgian Blue culled cows and growing fattening bulls: 1 characteristics of the cuts V Robaye, O Dotreppe, JL Hornick, L Istasse, I Dufrasne

150 Assessment of cut-off points during tuberculin skin test for the diagnosis of bovine tuberculosis in Cameroonian cattle

J Awah-Ndukum, C A Kudi, G Bradley, G S Bah

151 Effects of stearidonic acid supplementation on methane production evaluated in vitro

P Amaro, M R G Maia, R J Dewhurst, A J M Fonseca, A R J Cabrita

152 A comparison of two dietary regimes on weights and two morphometric characteristics of Belgian Blue-cross beef cattle over the winter housed period

H Scott-Browne, N Blackie, A Tibbott, R Cooke

153 Evaluation of moist co-products for finishing dairy-bred bulls

S P Marsh, C W Manley, R Wynn

154 Evaluation of skim and whey based milk replacers on the performance of artificially reared dairy-bred bull calves

S P Marsh, D T Boyd

155 Comparison of manual and Video Image Analysis classification systems for the prediction of yield and composition of the loin joint in commercial cattle

C R Craigie, C A Maltin, R W Purchas, D W Ross, L Bunger, S T Morris, R Roehe

\section{Highlights Blue}

156 Changes in equol concentrations during technological processing of control and isoflavone-enriched milk L Krizova, A Vesely, V Gencurova

157 Recurrent exertional rhabdomyolysis - prevalence and possible dietary risk factors in Thoroughbred racehorses

R Mundy, T Hollands, R Piercy, K Verheyen, L Salonen

158 Oleic acid supplementation favours basal prostaglandin $\mathrm{E}_{2}$ production and antagonizes the effect of oxytocin in uterine endometrial cells isolated from late gestation ewes

Z Cheng, D C Wathes, D R E Abayasekara, M Elmes, S Kirkup

159 The effects of replacing traditional inorganic zinc supplements with organically chelated zinc (Bioplex $\left.{ }^{\circledR} \mathrm{Zn}\right)$ supplements on performance in sheep

M K Cave, A M Mackenzie, R G Wilkinson, L A Sinclair

160 Footrot and other foot conditions in hill and lowland sheep: effects of flock, ewe breed, age and litter size C O Lynch, J P Hanrahan

161 Evaluation of fresh wet brewers grains as a replacement in a conventional fattening ration: intake, digestibility and nitrogen balance in goats

T S Sgwane, B J Dlamini, M Dlamini 
Preliminary study of Balangu, an Intermediate Moisture Meat, made from beef compared, with mutton and chevon, for food security

P Fakolade

163 The effects of environmental and physiological factors on the incidence of lameness in dairy sheep

A I Gelasakis, G Arsenos, G E Valergakis, G Banos

164 The peroxide value and thiobarbituric acids profiles of palm oil decanter meal kept over extended time

M Afdal, Kasim Azhar, A Razak Alimon, Norhani Abdullah

\section{SHEEP II}

165 Effects of substituting sesame oil for barley grain on rumen fermentation parameters and blood metabolites in lambs

H Ghafari, A A Khadem, M Rezaeian, A Afzalzadeh, S D Sharifi

166 In vitro rumen fungi growth in medium containing sugarcane pith treated with low temperature steam and acid using QC-PCR assay

M Chaji, T Mohammadabadi

167 The effect of soaking and urea treatments on the chemical composition of wheat straw

A Shirif, A Chaudhry, K Ben Hage

168 Effects of whole cottonseed on small intestine morphology of Chaal fattening male lambs

M Absalan, A Afzal zadeh, D Sharifi, A A Khadem, D Ghandi, A GH Zenouri

The effect of Samanea saman and Stylosanthes hamata supplementation on intake of Nerica 1 rice straw basal diet and NDF digestibility in Djallonké sheep

V Attoh-Kotoku, E L K Osafo

170 Effect of Holotrich protozoa on sheep methane emissions

A Belanche, A I Martín García, J M Moorby, C J Newbold

171 Effect of n-3 fatty acids supplementation on semen characteristics in Moghani rams

Mostafa Fouladi, F Mirzaei, M Shakuri, A Tohidi, Shahryar Kargar

172 Effect of sesame oil supplementation on fatty acid composition of tail fat and meat of Chaal lambs

H Ghafari, M Rezaeian, A A Khadem, S D Sharifi, A Afzalzadeh

\section{Nutrition}

173 The effects of yeast on the performance and welfare of heifers fed an organic finishing diet N D MacKintosh, K J Hart, C J Newbold

174 The role of tlr2 and dectin-1 in phagocytic and inflammatory response to antigen expressed on yeast surface R Patterson, P Dalby, Hans Martin S, D Werling

An investigation of the role of Insulin-Like Growth Factor 1 (IGF-1) in determining adult height of the horse R Reader, C Morgan, M Hegarty, N McEwan, W Powell, D Nash

A preliminary characterisation of the ecology of gut anaerobic fungal populations in horses R Birch, J Edwards, H Worgan, B Macias, P Rees Stevens, C Newbold, D Nash

In vitro kinetic characterization of inhibition of acetylcholinesterase by organophosphorus and carbamate compounds in food animals

K Abass Askar, A John Moody, A Caleb Kudi

178 Dogslife, a web-based epidemiological research project for prospective analysis of risk factors affecting the health of domestic dogs

D N Clements, M Bronsvoort, I Handel, D Querry, E Rose, K M Summers 
180 Effects of chicory / perennial ryegrass swards compared with perennial ryegrass swards on the faecal egg counts of grazing beef steers

C L Marley, R Fychan, J W Davies, R Sanderson, E Genever, A B Forbes

181 The effect of feeding pomegranate seed pulp on dry matter intake and performance of Iranian crossbred goats J Modarresi, MH Fathi Nasri, O Dayyani, L Rashidi, M Danesh Mesgaran, H Farhangfar

182 Improved extraction method for archaeol in faeces - a potential biomarker for methanogenic Archaea in the ruminant gastro-intestinal tract

C A McCartney, R J Dewhurst, R P Evershed, R D Pancost, I D Bull

183 Relationships between stage of growth and chemical composition of grass Haopeng Jiao, Tianhai Yan, D Wills

184 Histochemical localization of acetylcholinesterase in liver of food animals Kasim Abass Askar, A John Moody, A Caleb Kudi

185 A kinetic characterization of acetylcholinesterase and butyrylcholinesterase in the tissues of food animals Kasim Abass Askar, A John Moody, A Caleb Kudi

186 Silage fermentation end products and microbial populations and their relationships to silage quality of orange pulp S Lashkari, A Taghizadeh

187 Effects of supplementation of rice straw with readily digestible fiber on populations of fiber-associated ruminal microbes by real-time quantitative PCR in vitro

Xiaolian Chen, Jianxin Liu, Jiakun Wang

188 Effect of chemically processing using alum solution on in vitro gas production parameters of barley grain E Abdi Ghezeljeh, M Danesh Mesgaran, A R Vakili, H Nassiri Moghaddam

189 the effect of milking season on milk yield and composition of khuzestan water buffalo A Masoudi, M Chaji, M Bojarpour, H Albomohsen, S Rouzegar, S Rahimnahal

190 The effect of the low temperature steam $\left(142,130\right.$ and $\left.90{ }^{\circ} \mathrm{C}\right)$ and sulphuric acid on in vitro gas production parameters of sugarcane pith

T Mohammadabadi, M Chaji

191 Loss of activity of the putative protein protectant polyphenol oxidase (PPO) occurs as a result of preservation of red clover forage samples by freeze-drying

G E O'Keeffe

192 Effects of various Iranian native essential oils on in vitro ruminal methane emission and feed fermentation efficiency

H Jahani-Azizabadi, M Danesh Mesgaran, A R Vakili, K Rezayazdi, A R Heravi Moussavi, S Motazhary

\section{DAIRY I}

193 Seasonal variation of milk production, fat and protein percentage in Iranian Holstein dairy cows

J Faryadimehr, S Khalajzadeh, M Bagher Sayyadnezhad

194 The characteristics of extended lactations in the UK dairy herd

G E Pollott

195 Effect of dietary starch source and alfalfa hay particle size on chewing time and ruminal pH in mid-lactation Holstein dairy cows

S Mahmoud Nasrollahi, M Khorvash, G R Ghorbani 
196 Effect of $\mathrm{N}$ underfeeding and energy source on milk production and $\mathrm{N}$ partition in dairy cows A Fanchone, M Doreau, P Nozière

197 Effect of $\mathrm{N}$ underfeeding and energy source on ruminal digestion and protein metabolism in dairy cows A Fanchone, P Nozière, J Portelli, B Chauveau-Duriot, V Largeau, M Doreau

198 Effects of dry period length on the subsequent performance of lactating Holstein cows

R Jafari Jafarpoor, A R Heravi mousavi, M Danesh Mesgaran, A R Vakili

199 Evaluation of the inclusion of intact or physically broken flaxseed to extruded soya seed on Holstein lactating dairy cow performances

R Jafari Jafarpoor, M Danesh Mesgaran, S Gohari, S Danesh Mesgaran, M R Ghaemi

\section{DAIRY II}

200 A study of secondary follicles development in Iranian Raeini cashmere goat kids

S M Syeed Moumen, M V Tokasi, M Shamsaddini Bafti, N Karegar

201 Effects of probiotic and prebiotic on performance and plasma IgG1 concentration of dairy calves

N Dabiri, P Mohamadi, A Mahdavi, Ahmad Zare

202 Incremental effects of a novel calcium salt of cis-monounsaturated fatty acids product on milk fatty acid composition

K E Kliem, C K Reynolds, D J Humphries, R Kirkland, D I Givens

203 Resumption of cyclicity: its associations with metabolic profiles during the early postpartum period, body condition score and first service conception rate in a spring calving dairy herd

C O Lynch, D A Kenny, M G Diskin

204 Effects of replacing barley grain with starch processing wastage on production performance in Holstein dairy cows

M Rezaeian, J Honarzad, S S Mousavi

205 The effect of silage and concentrate type on milk fatty acids and the occurrence of subacute ruminal acidosis in dairy cows

E Colman, B Vlaeminck, S Abrahamse, J Dijkstra, V Fievez

206 Effect of dietary copper sulphate or organically complexed copper (Bioplex® $\mathrm{Cu}$ ) fed either without or with dietary $\mathrm{Cu}$ antagonists on the intake, performance and mineral status of early lactation dairy cows

K J Hart, A M Mackenzie, L A Sinclair

207 Effect of level of inclusion of copper sulphate and organically complexed copper (Bioplex $\left.{ }^{\circledR} \mathrm{Cu}\right)$ on indicators of $\mathrm{Cu}$ status, performance and milk fatty acid profile in dairy cows

K J Hart, A M Mackenzie, L A Sinclair

208 Calving ease and the subsequent occurrence of mastitis and lameness in dairy cows: retrospective analysis from a UK farm

A C Barrier, A I Macrae, M J Haskell

\section{Genetics}

209 Use of farmer recorded lameness data to improve the genetic evaluation of lameness in UK dairy cattle T Pritchard, M P Coffey, R Mrode, K Moore, E Wall

210 Estimated genetic parameters of calving performance in UK Holstein-Friesian cattle, using a multitrait animal model

S A E Eaglen, J A Woolliams, M P Coffey, E Wall 
212 Known mutations with large effects on ovulation rate not involved in the prolificacy of Finnish Landrace sheep M P Mullen, J P Hanrahan

213 Estimation of (Co)variance components for economical traits in Moghani sheep M Bayeriyar, A Asghar Aslaminejad, H Farajiarogh, F Bahri Beinabaj, M Danesh Mesgaran

214 Genetic and environmental parameters for ewe productivity in Moghani sheep S Savar Sofla, A Nejati Javaremi, M A Abbasi, R Vaez Torshizi, M Chamani, B Taheri Dezfuli

215 Estimation of variance components for reproductive traits of Zandi sheep H Mohammadi, M Moradi shahrebabak, M Sadeghi

Statistical comparison of partial regression coefficients of weaning weight on birth weight and weaning age in Iraninan Holstein calves

F Bahri Binabaj, H Farhangfar, P Rowlinson, H Faraji Arogh

217 Gibbs sampling optimization in Bayesian estimation of genetic parameters for some production traits of Iranian Holstein dairy cattle

S Alijani, M Jasoori, N Pirani, M B Sayadnejad

218 Estimates of genetic trend for reproductive traits in Iranian Holstein dairy cows M Honarvar, H Ghiasi

219 Fixed or random effect of contemporary group for estimating heritability of monthly test day milk yield in Iranian primiparous Holsteins

H Farhangfar, M Jafari Tarbaghan, P Rowlinson, M Bashtani, M Hassan Fathi Nasri

220 Study of Genotype by environment interaction for milk and fat yield in Iranian Holstein dairy herds S Savar Sofla, B Taheri Dezfuli, H R Seyedabadi

\section{Free Communications}

221 Can bioelectrical impedance analysis (BIA) be used as a method to measure muscle percentage in the live pig?

A E Taylor, S Jagger, P Toplis, I Wellock, H M Miller

222 Surveillance for potential mosquito viral vectors in the UK W Chadwick, R Blunt, J Daly

Comparative chemokine response to influenza virus infection between key primary human and pig cells G A White, S P Dunham, R K Nelli, I H Brown, S V Kuchipudi, K C Chang

224 Dilution effects on acetylcholinesterase and butyrylcholinesterase activities in the tissues of food animals Kasim Abass Askar, A John Moody, A Caleb Kudi

Defective viral replication and lack of pro-inflammatory cytokine response contribute to innate host resistance in $\mathrm{H} 5 \mathrm{~N} 1$ influenza virus infected primary pig cells R K Nelli, S V Kuchipudi, G A White, S P Dunham, I H Brown, Kin-Chow Chang

Differences in SPI gene expression in Salmonella enterica in macrophages differentiates systemic serovars from those restricted to enteritis A Imre, A Bukovinski, Xiangmei Zhou, P Barrow 


\section{INVITED}

\section{INTERPLAY BETWEEN IMMUNITY, ENDOCRINOLOGY AND NUTRITION}

227 New strategies on targeting host response to inflammation by novel dietary means for the purpose of reducing growth promoting antibiotics

M Cook, J Sand

228 Endocrines and host-pathogen interactions

T J Humphrey

\section{Availability of Feed Resources}

229 EU Feed legislation: what can we change?

T L Franck

\section{Global Food Security}

$230 \quad$ Continuous housing of dairy cows: challenges and opportunities

J M Wilkinson, P C Garnsworthy, J N Huxley

\section{Equine Exotic Diseases: potential Risk AND PREvention measures in the UK IN A}

\section{CLIMATE CHANGING WORLD}

231 The risk of exotic disease and the threat to the equine industry

P Jepson

$232 \quad$ West nile virus

D Hannant

$233 \quad$ African horse sickness

J Castillo-Olivares

\section{Equine Performance, Nutrition and Health}

234 Welfare issues for horses competing in international equestrian competitions C Roberts

\section{President's Session - Food Security}

235 Food security - challenges and opportunities for animal science A Bell

236 The new food security challenge: balancing agriculture, health and environmental sustainability M Winter

\section{The Gut Microbiome}

237 Human metagenomics in the gut

J Marchesi

238 Rumen microbial ecology and its role in cattle feed efficiency

L Guan

239 Non-ruminant - host microbial interaction in the gut I E Mulder

\section{Companion Animal Health and Disease}

240 Management of obesity in dogs and cats - maximising success

A J German 